\title{
A New Origin of Life and the Universe Proposed- Microzymian!
}

\author{
Seun Ayoade* \\ Department of Physiology, University of Ibadan, Nigeria
}

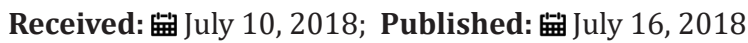

*Corresponding author: Seun Ayoade, BSc (Hons) Physiology, University of Ibadan P.O. Box 22325, Oyo State, Nigeria

\section{Introduction}

I propose a microzyma/microzymian theory of the origin of life to wit I propose a theory of the origin of life that states that life as we know it arose from the first ever microzyma! Microzyma are found on/in air, rocks etc. What if the microzyma, in ages past synthesized the air, rocks, mountains etcetera? Microzyma have never been observed to perish. What if microzyma made the universe? Microzymian reactions/activities have been observed to produce chemicals and minerals. Couldn't the first microzyma/ group of microzyma have produced the first element or elements?

I propose that the origin of biological life and of the entire physical universe is the microzyma. The atom has been split, the microzyma has not. Rocks have been split and ground to dust, the microzyma have not. It appears the only indestructible thing on this earth are the microzymas. Microzymas are never formed or born and never decay or die. It is not completely unreasonable therefore [till it is proven otherwise] to propose that they were in existence before everything else and that they made everything else, and that they will continue to exist after everything else whether living or non-living is gone. Microzyma are found everywhere and in/on everything, living or non-living. They are found in the air, mountains, sea, fire and ice. No terrain, temperature or territory can stop them. They can go and thrive where germs cannot. Bacteria, viruses, protozoa, fungi and even genes, chromosomes and DNA deteriorate, deactivate or die where microzyma remain alive and kicking. This microzymian theory of life does not rule out/is not entirely incompatible with intelligent design, the big bang (the microzyma could have set it off!), the steady state theory, cosmozoanism/ panspermia, some aspects of the conventional theory of evolution. The theory does not necessarily deny the existence of a creator.

\section{References}

1. A Bechamp (2010) Blood and Its Third Anatomical Element Kessinger Legacy Reprints p. 26-27.

2. Seun A (2017) Koch's Postulates and Germ Terrain Dualism; Cellular Dust as Yet another Term for Microzymas. JOJ Nurse Health Care 5(4): 555666.
(C) This work is licensed under Creative

To Submit Your Article Click Here: Submit Article

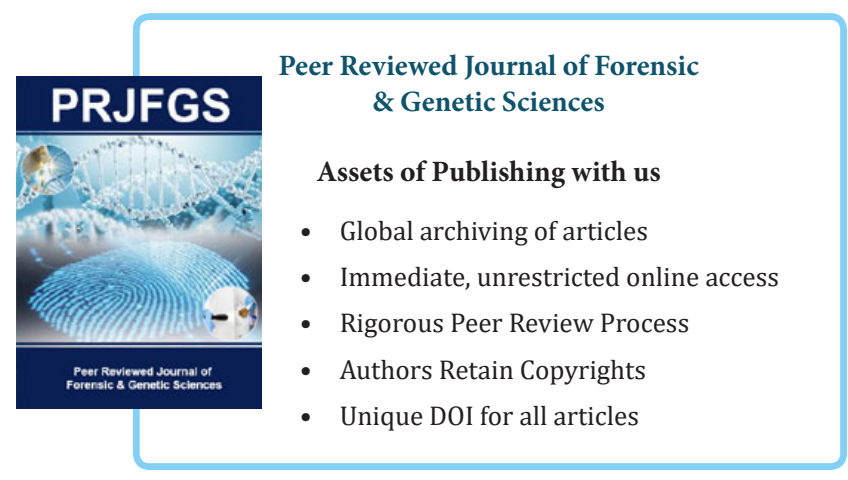

